\title{
SPRAWOZDANIA
}

\section{ZJaZd KaTEDR PRAWA RZYMSKIEGO \\ OSTRÓDA 16-18 CZERWCA 2006 ROKU}

W dniach 16-18 czerwca 2006 odbyło się w Ostródzie Spotkanie naukowo-szkoleniowe romanistów poświęcone zagadnieniu Prawo rymskie - Interpretacja.

Organizatorami Spotkania, nad którym honorowy patronat objąi JM Rektor Uniwersytetu Warmińsko-Mazurskiego w Olsztynie prof. dr hab. Ryszard J. Górecki, byli prof. dr hab. Witold Wołodkiewicz (Przewodniczący Komisji Praw Antycznych KNoKA) i prof. dr hab. Bronisław Sitek, kierownik Katedry Prawa Rzymskiego i Porównawczego UW-M.

Otwarcia zjazdu dokonał Dziekan Wydziału Prawa i Administracji UW-M, prof. dr hab. Stanisław Pikulski. Następnie uczestników w imieniu organizatorów powital prof. Sitek.

Pierwszy dzień obrad podzielony został na dwie sesje. Podczas pierwszej, której przewodniczył prof. Witold Wołodkiewicz z Uniwersytetu Warszawskiego, prof. dr hab. Maria Zabłocka (UW) przedstawiła referat pt. Stan badań polskiej romanistyki. Druga sesja, której przewodniczył prof. Marek Kuryłowicz z Uniwersytetu Marii Curie-Skłodowskiej, poświęcona była zagadnieniom rzymskiego prawa karnego. Jako pierwszy referat wygłosił dr Jacek Wiewiorowski (UAM), który mówił o 'Officium ducis' $w$ Cesarstwie wschodniorzymskim. Kolejne referaty wygłosili dr Krzysztof Amielańczyk (UMCS): Twórcza interpretacja 'legis Corneliae de sicariis et veneficis' przez Hadriana i jurysprudencje cesarska, dr Marzena Dyjakowska (KUL): 'Crimen laese maiestatis divinae' $w$ literaturze $X V I$ i XVII w, ks. dr Piotr Sadowski (UO): Rzymskie prawo karne w ujeciu Contarda Ferriniego, dr Ryszard Sajkowski (UW-M): $W y$ - 
brane problemy oskarżenia Gajusza Syliusza i jego matżonki Sozji, mgr Piotr Kołodko (UwB): Chtosta jako kara w rzymskim wojskowym prawie karnym, mgr Adam Świętoń (UW-M): Przymus stużby wojskowej w późnym cesarstwie rzymskim. Rozważania na tle Kodeksu Teodozjańskiego, mgr Maciej Jońca (KUL): Prawo rzymskie a rewolucja (Gerhard von Beseler contra Gustav Radbruch), mgr Anna Pawłowska (UMCS): Sposoby wykonania kary śmierci w państwie rzymskim.

Po wysłuchaniu referatów prof. M. Kuryłowicz otworzył i moderował dyskusję.

W drugim dniu zjazdu moderatorem porannej sesji był prof. Jan Zabłocki z UKSW. Referaty wygłoszone podczas tej sesji dotyczyły rzymskiego prawa prywatnego. Jako pierwszy głos zabrał prof. Marek Kuryłowicz (UMCS), który w referacie Swetoniusz, Caligula 38. Próba interpretacji wskazal na pojawiające się w tym tekście problemy interpretacyjne. Drugi referat, wygłoszony przez prof. Tomasza Giaro (UW) poświęcony był zagadnieniu Interpretacja jako źródto prawa okresu Pryncypatu. Kolejnymi prelegentami byli dr Rafał Wojciechowski (UWr): Doktryna Azona o 'vir bonus', dr Renata Świrgoń-Skok (URz): Beneficjum - przeglad źródet, dr Rita Jaworska-Stankiewicz (USz): 'Delegatio' $w$ prawie rzymskim $i$ w prawie polskim - zarys problematyki, mgr Paulina Święcicka (UJ): Interpretacja adaptacyjna na gruncie jurysprudencji rzymskiej na przyktadzie wybranych spraw z zakresu odpowiedzialnosci akwiliańskiej. Kolejne referaty obracały się wokół zagadnień prawa osobowego i rodzinnego. Dr Elżbieta Ejankowska (URz) omawiała zagadnienie Emancypacja społeczno-gospodarcza kobiet rzymskich w okresie późnej republiki i pryncypatu, a mgr Krzysztof Szczygielski (UwB) opisał Konkubinat a zasady porzadku i moralności publicznej w starożytnym Rzymie. Trzy ostatnie wystąpienia wygłosiły mgr Aldona Jurewicz (UW-M): Interpretacja tekstu Modestyna D. 23.2.24, rozstrzygnięcie klasyczne czy późniejsza interpolacja?, mgr Aleksandra Paczkowska (UG): Terminologia zwiazana $z$ instytucja konkubinatu $w$ prawie rzymskim - interpretacja wybranych pojęć, mgr Klaudia Jerz (UMCS): Obywatelka rzymska 'utomna osoba fizyczna'. 
Sesję tą zakończyła krótka dyskusja.

Druga sesja tego dnia poświęcona była historii prawa rzymskiego, a przewodniczył jej prof. Tomasz Giaro z Uniwersytetu Warszawskiego. Pierwsze referaty wygłosili prof. Bronisław Sitek (UW-M): Stosowanie prawa rzymskiego w ustawach municypalnych. Studium prawno-historyczne na tle 'Tabula Heracleensis' $i$ 'lex Irnitana', dr Marek Sobczyk (UMK): Prawo rzymskie przed Europejskim Trybunałem Sprawiedliwości i dr Lukasz Marzec (UJ): Wizja prawa rzymskiego w Europie w świetle poglądów Artura Ducka. Kolejnymi referentami byli ks. dr Stanisław Jóźwiak (KUL): Rola biskupa w państwie rzymskim w świetle korespondencji św. Augustyna oraz dr Miron Wolny (UW-M): Lex Claudia a rozwój kariery politycznej Gajusza Flaminiusza. Sesję zakończyły wystąpienia mgr Renaty Wiadernej-Kuśnierz (UMCS): Prawo rzymskie na Uniwersytecie Jana Kazimierza we Lwowie w okresie międzywojennym i mgr Karoliny Chytły (UJ): Prawo rzymskie kluczem do zrozumienia dziedzictwa prawa prywatnego Europy.

Spotkanie zamknęła dyskusja nad przyszłością polskiej romanistyki.

Agnieszka Stępkowska*

\section{'CUIUS REGIO EIUS RELIGIO?' - ZJAZD HISTORYKÓW PAŃSTWA I PRAWA, LUBLIN 22-24 WRZEŚNIA 2006 ROKU}

W dniach 22-24 września 2006 r. odbył się zorganizowany przez Katedrę Historii Państwa i Prawa Katolickiego Uniwersytetu Lubelskiego Zjazd Historyków Państwa i Prawa. Wzięli w nim udział przedstawiciele ośrodków uniwersyteckich w Polsce. Łącznie referaty wygłosiło 60 osób.

Zjazd otworzył - rano w piątek 22 września w Collegium Jana Pawła II - prof. Grzegorz Górski, Kierownik Katedry Państwa i Prawa KUL. Powitał on przybyłych, a następnie uczynił to ks.

\footnotetext{
* Uniwersytet Warszawski.
} 